\title{
Development and Future Prospects of Labour Law
}

\section{Introduction}

Present labour law is not the same as it was thirty years ago. It has be$\int$ come more complex. There exist new legal creations, new protections, and new rights. Some of these novelties are connected with the direct application of the Constitution to the relationships between individuals (horizontal effectiveness) and the breakthrough of the fundamental rights of individuals within the labour contract, which have made it possible to widen the worker's protection and limit the employer's powers. Others are related to the reactions, within the field of labour law, to the phenomenon of corporate decentralisation and labour fraud, which has led to protective legal solutions Collective bargaining offers nowadays more varied and complex contents than in the past. In many countries, collective bargaining is a common practice in the public sector. Some time ago, it was accepted but still difficult to put into practice.

Labour law has evolved strengthening its own distinct features. This has made it possible to resort to rules of general law in case of a legal vacuum or a loophole in labour law, without risking that its specificity may be questioned.

The use of varied mechanisms within law to ensure the operation of labour rights should be highlighted as a difference from what used to happen in the past.

The concept of subordination is still the decisive element to determine the protection, notwithstanding the fact that, within certain systems, autonomous workers enjoy several subordinate workers' rights.

Case-law has played a key part in constructing labour law and bringing it to this point, at least in many Latin American countries, notwithstanding the role of legislation as an instrument of social change and of collective bargaining.

* Dr, Professor of Labour Law and Social Security, School of Law, University of the Republic, Montevideo, Uruguay, Vice-President of the International Society for Labour and Social Security Law (2006-2009). 
The progress that labour law has made and its present state set the challenges that the field will have to face in the future.

This work analyses changes in labour law at the current stage of its development, both in Latin America and Europe, which I believe may shed light on the future of this branch of law.

\section{Direct application of the Constitution}

At present, constitutional principles are relied upon aiming at providing workers with greater protection.

The acceptance of the application of the Constitution to the relationships between individuals (horizontal effectiveness) has brought about changes significant in labour law but also in law in general ${ }^{1}$. The whole field of law could be 'reformulated' based on the fundamental rights applied directly from the Constitution.

However, this must not lead us into excesses implying a change of legal disciplines that may no longer be identified in their specificity, nor must it cause excesses in judges' interpretation of the Constitution ${ }^{2}$. It has been appropriately stated that interpretation 'from' the Constitution may not be excuse to amend the law, nor to interpret it in a different sense if the rule's tenor or the end pursued by the legislator is clear. Moreover, not all constitutional precepts can be applied directly ${ }^{3}$.

In some Latin American countries, judges rely upon what is called 'bloque de constitucionalidad' (legal rules with a constitutional role, complementing constitutional provisions), usually to base the application of the individual's fundamental rights to the worker within a labour relationship.

\section{Individual's rights within a labour contract and limitations to the employer's powers}

The idea that the worker holds in the company his/her personal/ human rights has been received in Latin America and Europe. Some define it as a 'refoundation' of labour law based on human rights'; others

${ }^{1}$ Experts in civil law ask whether we are before a new constitutionalized civil law, see J. Gamarra, Neoconstitucionalismo, código y ley especial, FCU, Montevideo 2012, p. 6.

2 There are warnings against possible excesses of Neoconstitutionalism which confers ample powers to judges. It is pointed out that false oppositions are brought up which can only be explained through an out-of-date legalistic positivism (J. Gamarra, Neoconstitucionalismo, código y ley especial..., p. 9).

${ }^{3}$ M. Risso Ferrand, Derecho constitucional, t. I, Fundación de Cultura Universitaria, Montevideo 2005, p. 249.

${ }^{4}$ In this sense F. Gaudu, Informe Francia 'Libéralisation des marchés et droit du travail', XVII World Congress of Labour Law and Social Security, Paris 2006, p. 7. 
state that the application of the fundamental rights to the labour contract is an element of 'renovation and progress' of labour law as a whole ${ }^{5}$. It is even pointed out that it leads to the dogmatic reformulation of the legal positions of the parties to the labour contract ${ }^{6}$.

The application of the workers' human rights to the labour contract has broadened the workers' protection system in several countries. This has been possible due to its acknowledgement by the judges, notwithstanding the fact that on some occasions the protection was set forth by legislation ${ }^{7}$.

In the future of labour law, human rights will continue to play a relevant role as a means of limiting the employer's powers. Nevertheless, it must be taken into consideration that the employer's managerial power derives from the freedom of undertaking acknowledged in the constitutions ${ }^{8}$. Therefore, in case of conflict with the workers' human rights, the issue shall be considered a conflict of fundamental rights and the judge shall seek their harmonization resorting to good judgement of the same.

\section{Corporate decentralisation and response from labour law}

Technological changes in the organization of work and ways of performing work have had multiple repercussions in several aspects of labour law. In few years, we have witnessed the rise of varied ways of work which diverge from subordinate work and differ from country to country (service contracts, cooperative associations, professional associations, business associations, etc).

Labour law has responded rapidly and firmly against labour fraud and decentralisation of production, designing and improving protective legal mechanisms. It has accurately been stated that, in many countries, the labour law systems have been able to resist the pressures of globalisation and have not been destroyed ${ }^{9}$. Let us consider some examples of new solutions introduced in labour law.

${ }^{5}$ J. Rivero Lamas, Derechos fundamentales y contrato de trabajo: eficacia horizontal y control constitucional, El trabajo y la Constitución, Estudios en homenaje al Profesor Alonso Olea, Ibero-American Academy of Labour Law and Social Security, Spanish Ministry of Labour and Social Affairs, Madrid 2003, p. 527.

${ }^{6}$ F. Valdés dal Ré, Los derechos fundamentales de la persona del trabajador, Informe general XVII World Congress of Labour Law and Social Security, 2-5 September 2003, Book of general reports, FCU, Montevideo 2003, p. 41.

7 In Chile, for example, protection of the workers' fundamental rights has a specific procedure in the law.

8 A. Jeammaud, Libertés et pouvoir. Un double paradoxe et un paradoxe apparent, Supplément à la Semaine Social Lamy, n⿳ํㅡㄹ 1908, Paris 2011, p. 137; F. Valdés dal Ré, Los derechos fundamentales..., p. 91 and 99.

${ }^{9}$ L. Compa, Trade liberalization and labour law. General report, XVIII World Congress of Labour Law and Social Security, Paris, 5-8 September 2006, Paris 2006, pp. 1-12. 


\section{A. The search for the employer}

In many cases, it has been necessary to 'search' for the real employer when the primacy of reality over contract types proves relevant. Some systems have introduced legislative provisions to fight labour fraud, and in others this is done by resorting to legal scholars' and judges' criteria. Nevertheless, in still other situations, there is no labour fraud but a shift in the companies' organization of work. The legal profile of the employer disperses and he/she is no longer just one entity who gives orders, pays salaries and receives work. In some cases, one company hires employees and pays salaries and another one gives orders.

This is why, in several countries solutions have been designed to accurately determine the characteristics of the employer. Along this line, we may find the concept of 'labour business group' or 'complex employer'.

\section{B. Labour responsibility of the company hiring the services}

Labour law has responded accordingly offering protective solutions to the challenges brought by decentralisation of production.

It is not an extension of the employer's responsibilities, since in many cases the company is not the employer and anyway responds jointly or subsidiarily. Some countries have passed laws which set forth the liability of the main company in case of sub-hiring and provision of labour force $^{10}$. The aim is not only to prevent fraud but also to achieve greater protection of labour credits guaranteeing workers' collection thereof.

\section{Harassment and violence in the workplace and new labour protections}

It is worth mentioning the impact that harassment and violence in the workplace have had in labour law in the recent years. This is bound to continue in the future since it implies a cultural change in labour relationships.

In many countries, this matter has been regulated by law or the labour code. The respective regulations have acknowledged new rights of workers (the right to an investigation in case of an accusation, the right to be protected by the employer during the investigation, etc.) and limited the employer's powers of management and discipline (compelling him/

${ }^{10}$ In Chile and Uruguay, for example. In Raffaele De Luca-Tamajo and Adalberto Perulli's general report Labour Law (in Its Individual and Collective Aspects) and Productive Decentralisation at the XVIII World Congress of Labour Law and Social Security, protective mechanisms against subcontracting, joint liability and fighting against labour fraud can be found in several countries, Paris, 5-8 September 2006, pp. 63-71. 
her to sanction the harasser in case harassment can be proved $)^{11}$. Moreover, the indemnification of moral damage within the labour contract has been accepted, which used to be a subject of dispute in the past.

\section{Return to the general principles and general law or a crisis of specificity in the future of labour law?}

The application of general law in the sphere of labour law in case of loopholes in the labour regulations has been admitted in many countries, while respecting the specificity of this law, in other words, accepting the application of the civil or general law provisions only in case of a vacuum in the actual labour regulations.

A return to ordinary concepts of law can be observed, yet not in order to replace specificities of the special law but to broaden or improve them.

In my view, this implies progress in labour law. Labour law is already consolidated yet draws on civil law (or general law) to supplement its solutions, broaden or rework them, but always in case of a loophole in the labour law and as long as no provision, concept or principle of labour law is contravened. This way, the resort to a civil law rule or solution is without detriment to the specificity (or autonomy) of labour law. I shall offer a few examples below.

Labour definitions and concepts have been designed based on civil law regulations. This is the case of the 'complex employer' concept created by the case-law in Uruguay ${ }^{12}$. This concept has made it possible to face certain changes that have taken place in the organization of work, searching for the real employer or simply broadening the liability of the company which hires services.

Civil law regulations and concepts have also been used to limit the employer's powers. This has been the case, for example, of ius variandi and disciplinary power. The French Court of Cassation relied on civil law provisions that govern contracts in order to limit the employer's right to introduce amendments to employment contracts ${ }^{13}$. The employer's

${ }^{11}$ It is set forth by the Uruguayan Act No 18.561 dated 11 September 2009 on sexual harassment in labour and teaching relationships. There are similar legal and case-law solutions in several countries.

${ }^{12}$ For example, in the case of workers from company A who work at the premises of such company, and who are directed by supervisors of company B for whom the work is performed. Case-law has provided that both companies take responsibility for the whole, since they have contracted indivisible obligations (section 1384 of the Uruguayan Civil Code).

13 A. Jeammaud, The Contribution of the Court of Cassation in the Construction of Labour Law in France, VII American Regional Congress of Labour Law and Social Security, Santo Domingo, Dominican Republic, 31 October to 2 November 2007, unpublished keynote lecture. 
managerial and disciplinary powers have also been limited by the obligation to act with good faith when performing a contract ${ }^{14}$.

A different issue is resorting to civil or general law in order to apply force against the specificities of labour law or to simply eliminate them. At present, there is a trend of thought which proposes the application of general or civil law principles even if this means violating what is stated by a labour law provision or principle. It is argued that in a specific case resorting to civil law (or general law or general principles) becomes more beneficial to the worker ${ }^{15}$.

I believe that the use of civil concepts and rules (or general principles) when a labour rule or concept sets forth a different solution to general law is not only unlawful - since the special rule voids the general one - but also infringes the specificity (or autonomy) of this branch of law and jeopardises its particularity.

\section{Universal nature of labour rights and changes to the sources of positive law - can an international social public policy guarantee some of the rights?}

One of the matters which at present shows up as of paramount importance and which will remain relevant in the foreseeable future of labour law is the global scope regarding both labour rights and the various means to achieve their effective legal force. The idea is being pushed forward as there are some specific labour rights which should be established and exercised in any country where a company's activity is conducted. It involves universally applicable workers' rights and new ways to implement them.

It is interesting to observe how this matter has brought changes in the labour law sources. Together with the statute law and collective bargaining units, legal implements are introduced which far from lessening the current working conditions are just aimed at achieving global effectiveness of labour regulations.

There have been several means towards this aim recently. I will only mention some of them.

${ }^{14}$ The Uruguayan Supreme Court of Justice in the judgement 418/2003 stated that the employer that carries out an inquiry must respect its outcome. If there is no liability from the worker, he/she cannot be dismissed. If he/she were dismissed, there would be abuse of authority for not complying with the obligation to act with good faith. The Court sentenced the employer to pay an indemnification for moral damage.

${ }^{15}$ For example, it is intended to broaden the employer's liability in case of labour accidents. It is proposed to leave behind fixed-rate indemnifications and apply the general principle of integral indemnification of damage, even going against the labour rule. 


\section{1998 ILO Declaration on Fundamental Principles and Rights at Work}

This Declaration may be considered an approach to an 'international social public policy' as it states that Members, for the mere fact of pertaining to the Organization, make the pledge to respect and strive for the actual effectiveness of the said principles and fundamental rights having or not ratified the concerning International Labour Convention ${ }^{16}$. The system through which the Declaration gives a compulsory quality to the fulfilment of those principles and fundamental rights is of particular interest.

The coming years will surely see an expansion of this group of principles and fundamental labour rights contained in the Declaration. Nevertheless, according to Alain Supiot, that list might be 'complemented' with other declarations of the International Labour Conference itself, as it was observed in the case of the social security law considered a fundamental human right by the Conference in its $200989^{\text {th }}$ meeting ${ }^{17}$.

\section{MERCOSUR Social and Labour Declaration}

In recent years, several acts in Uruguay have referred to MERCOSUR Social and Labour Declaration, allowing the conclusion that for the Uruguayan lawmaker that Declaration is the positive law ${ }^{18}$.

This Declaration contains compromises agreed upon by the Party States (for instance, to adopt policies and actions leading to the elimination of child labour, under Article 6). Therefore, in my opinion, the fulfilment of those compromises can be claimed. The judgements of Uruguayan Labour Judges often refer to the MERCOSUR Social and Labour Declaration among other regulations.

\section{Social clauses in free trade treaties}

Beside the critical opinions given about these legal instruments and their social contents, there are some cases where requirements may lead to the fulfilment of labour regulations and to respect of the labour rights.

16 A. Supiot states that it is one of the possible interpretations of the declaration, $\mathrm{La}$ place de la sécurité sociale dans le système des normes internationales du travail, Sémaine sociale Lamy, Supplément No 1272, Paris 2006, p. 8.

17 Ibidem, p. 9.

18 For example, Uruguayan Act No 17.940 dated 2 January 2006 declares void any discrimination aimed at diminishing the union freedom "in accordance [...] with paragraphs (a) and (b) of section 9 of MERCOSUR Social and Labour Declaration". 
It has been noted that a free trade treaty can set up a 'better guarantee' to enforce the labour rights due to being a contractual term and, therefore, enforceable in the countries ${ }^{19}$.

\section{Companies' Code of Conduct addressed to the personnel}

Codes of conduct issued by companies voluntarily within the corporate social responsibility are statements on social subjects that the companies prescribe to be complied with in every company within the social and economic group, irrespective of the country where any of them operates. Many of these codes include references to essential rights in the workplace, basic labour rights and working and environment conditions for the personnel.

These instruments have been frequently neglected or considered of lesser importance and just philanthropic marketing corporate policies. Others distrust these 'voluntary' statements defined as means to avoid the making of legislative rules. It has been reasoned that being statements concerning abstract concepts such as 'values' that inspire the corporations or mere 'intentions', they lack coercive mechanisms to apply the rules which remain subject to the company's single will ${ }^{20}$.

Nevertheless, from my point of view, the contents in many of these codes of conduct involve neither programmatic topics nor statements on values or intentions. On the contrary, in these codes corporations agree that personnel rights exist and guarantee the minimal acceptable conditions for the working environment. In my opinion, if the code of conduct recognises labour rights, once the code is notified to the employers, it becomes enforceable.

It should be kept in mind that in many of these codes of conduct corporations admit benefits which surmount the minimum that cannot be waived or renounced, or state proceedings for investigation or for protection of rights which are not provided by legislation. That is why, it is of paramount importance to state that these instruments cannot be considered 'soft law' in all cases. This will depend on the text of the company's statement (and on its following notification to the employees).

The French Court of Cassation holds that the corporate unilateral statements should be included in the collective statute, if not in the em-

19 M. Pasco Cosmópolis, Dimensiones laborales de la globalización: Lo laboral en los procesos de integración y los tratados de libre comercio, Laborem, Peruvian Association of Labour Law and Social Security, No 5, Lima 2005, pp. 87-121.

${ }^{20}$ International Organization of Employers, Position on codes of conduct, Geneva, 11 June 1999, p. 8-9, available at www.ioe-emp.org. 
ployment contract. This implies a greater flexibility ${ }^{21}$. It is still worth highlighting that these unilateral statements have legal consequences and they can be binding duties for the employers.

\section{Codes of conduct for suppliers}

Some companies design codes of conduct that contain a set of basic labour rights that suppliers must comply with in order to work with a multinational company.

It has been stated that these codes are not applied by companies in developing countries. Nevertheless, it is observed that these codes have had their impact in the field of labour law since contracts with suppliers have been rendered invalid due to non-compliance with the regulations concerning labour rights and working conditions set forth in the abovementioned codes $^{22}$.

Although these codes of conduct make up 'soft law', in practice, they lead to the acknowledgement of labour rights or to a wider compliance with labour regulations. Apart from the trade unions' actions, there are 'new actors' (human right organizations, organizations for protection of migrant workers, consumer protection, etc.), which denounce non-compliance with labour rights by suppliers of multinational companies ${ }^{23}$.

Having said this, although diverse, all the instruments which I have mentioned above (principles and rights declaration, social clauses, codes of conduct) have a common element in their contents: they require compliance with a number of fundamental work rights and basic labour rights.

These rights constitute the common core of labour rights, which become obligatory and enforceable, based on different sources, or which are applicable, in practice, through diverse mechanisms.

The system of labour law sources has experienced changes. It has been considered whether we are facing a normative evolution or a revolution ${ }^{24}$,

${ }^{21}$ A. Jeammaud, a keynote lecture at the VII American Regional Congress of Labour Law and Social Security, Santo Domingo 2007, already cited.

${ }^{22}$ In the Peruvian report Liberalización del comercio y derecho del trabajo at the XVIII World Congress of Labour Law and Social Security, it is stated that in the agro-industrial and textile sectors' contracts with certain suppliers have been rejected because they have not complied with the standards of the codes of conduct (A. Villavicencio, Peruvian report “Liberalización..., Paris, 5-8 September 2006, Paris 2006, p. 12).

${ }^{23}$ See R. Locke, T. Kochan, M. Romis, F. Qin, Beyond Corporate Codes of Conduct: Work Organization and Labour Standards at Nike's Suppliers, "International Labour Review, International Labour Organization" 1987, vol. 126, No 1-2, pp. 21-43.

${ }_{24}$ J.-C. Javillier, Gouvernance, Normes Internationales et responsabilité sociale de l' entreprise, Séminaire, Genève, 3-4 July 2006, available at www.ilo.org/public/french/bureau/inst/ papers/confrnce/gover2006/index.htm. 
and resorting to soft law has been proposed as a complement of dura lex ${ }^{25}$ or in combination ${ }^{26}$.

The most relevant change may be the delimitation of a common core of universal labour rights, which is similar (though not identical) in various instruments.

Although this trend has benefitted from the challenges posed by globalisation, it goes beyond this. It is related more precisely to the universal respect of labour rights, with a social public order, which in the future shall most probably be an international social public policy. To my mind, this will not only include subordinate work, since some of the principles and rights contained in the mentioned instruments also refer to autonomous work (for instance, prohibition of child labour, or the right to work in an environment free from discrimination or workplace harassment).

This is connected with a trend that has been announced but not completed yet and concerning the broadening of labour law to contain all types of work, including several contract types and different levels of protection.

\section{Conclusions}

1. Present labour law is not the same as traditional labour law, but in general terms it does not constitute lower protection. Labour law has responded to corporate decentralisation, labour fraud and the challenges posed by globalisation. Notwithstanding every country's specific case, labour law appears strengthened - at least in some regions - by criteria and protections which are complementary to those of traditional labour law.

It is the evidence that this branch of law has the necessary tools to face other changes regarding ways in which work is performed that will most probably take place in the years to come.

2. Universal nature of labour rights and their application in all countries by means of different sources and mechanisms is an issue of major importance. There is a common core of universal labour rights which is recurrent in the different instruments and which must be respected in all countries.

${ }^{25}$ A. Supiot, La place de la sécurité sociale..., p. 8-9.

${ }^{26}$ J.-C. Javillier, Interview with Jean-Claude Javillier, "Revista Relaciones Laborales" [Montevideo] 2006, No 12, p. 26. Adrian Goldin states that the company's voluntary initiatives are acceptable to improve the imperative body of laws, Sobre los códigos de conducta y otras iniciativas voluntarias de las empresas; ¿es la autorregulación empresaria una respuesta válida?, International colloquium on the $80^{\text {th }}$ anniversary of the ILO Committee of Experts, Ginebra 24-25 November 2006, p. 17. 
There are also changes introduced in the system of sources of law.

Some legal instruments may indicate a shift towards an international social public policy to be applied - at least in respect of certain rights - not only to subordinate work but to all work.

3 . The use of concepts directly related to general law, while respecting the specificity (or autonomy) of labour law, that is to say, applying them only in cases of a loophole in the labour rule, shall make it possible to continue broadening or re-elaborating this law specificity. The application of general law without respecting the labour regulations jeopardizes this branch of law.

\section{Bibliography}

Compa L., Trade liberalization and labour law. General report, XVIII World Congress of Labour Law and Social Security, Paris, 5-8 September 2006, Paris 2006, pp. 1-12.

De Luca Tamajo R., Perulli A., General report "Labour law (in its individual and collective aspects) and productive decentralisation" en el XVIII World Congress of Labour Law and Social Security, Paris, 5-8 September 2006, Paris 2006, pp. 63-71.

Gamarra J., Neoconstitucionalismo, código y ley especial, FCU, Montevideo 2012, p. 6 y 9.

Gaudu F., Informe Francia 'Libéralisation des marchés et droit du travail', XVII World Congress of Labour Law and Social Security, Paris 2006, p. 7.

Goldin A., Sobre los códigos de conducta y otras iniciativas voluntarias de las empresas; ies la autorregulación empresaria una respuesta válida?, International colloquium on the $80^{\text {th }}$ anniversary of the ILO Committee of Experts, Ginebra, 24-25 november 2006, p. 17

Javillier J.-C., Gouvernance, Normes Internationales et responsabilité sociale de l'entreprise, Séminaire. Genève, 3-4 juillet 2006, Genève 2006. www.ilo.org/public/french/bureau/ inst/papers/confrnce/gover2006/index.htm

Javillier J.-C., Interview with Jean-Claude Javillier, "Revista Relaciones Laborales" [Montevideo] 2006, No 12, p. 26.

Jeammaud A., The contribution of the Court of Cassation in the construction of Labour Law in France, VII American Regional Congress of Labour Law and Social Security, Santo Domingo, República Dominicana. 31 October to 2 November 2007. Unpublished keynote lecture.

Jeammaud A., Libertés et pouvoir. Un double paradoxe et un paradoxe apparent, Supplément à la Semaine Social Lamy, nº 1908, Paris 2011, p. 137.

Locke R., Kochan T., Romis M., Qin F., Beyond corporate codes of conduct: Work organization and labour standards at Nike's suppliers, "International Labour Review. International Labour Organization" 1987, vol. 126, No 1-2, pp. 21-43.

Pasco Cosmópolis M., Dimensiones laborales de la globalización: Lo laboral en los procesos de integración y los tratados de libre comercio, "Laborem, Peruvian Association of Labour Law and Social Security" [Lima] 2005, No 5, pp. 87-121.

Risso Ferrand M., Derecho constitucional, t. I, Fundación de Cultura Universitaria, Montevideo 2005, p. 249.

Rivero Lamas J., Derechos fundamentales y contrato de trabajo: eficacia horizontal y control constitucional, El trabajo y la Constitución, Estudios en homenaje al Profesor Alonso Olea, Iberoamerican Academy of Labour Law and Social Security, Spanish Ministry of Labour and Social Affairs, Madrid 2003, p. 527. 
Supiot A., La place de la sécurité sociale dans le système des normes internationales du travail, Sémaine sociale Lamy, Supplément no 1272, Paris 2006, p. 8 y 9.

Valdés dal Ré F., Los derechos fundamentales de la persona del trabajador, Informe general XVII World Congress of Labour Law and Social Security, 2-5 September 2003, Book of general reports, FCU, Montevideo 2003, p. 41.

Villavicencio A., Peruvian report "Liberalización del comercio y derecho del trabajo" at the XVIII World Congress of Labour Law and Social Security, Paris, 5-8 September 2006, Paris 2006, p. 12.

\section{Rozwój i perspektywy prawa pracy}

\section{Streszczenie}

Obecne prawo pracy nie jest takie samo jak trzydzieści lat temu. Stało się bardziej złożone. Powstały nowe konstrukcje prawne, nowe rodzaje ochrony, nowe prawa. Część z tych nowości wiąże się z bezpośrednim stosowaniem konstytucji do stosunków między jednostkami (bezpośrednia skuteczność) i przeniknięciem indywidualnych praw podstawowych w sferę umowy o pracę, dzięki czemu uległa poszerzeniu ochrona pracownika, a ograniczeniu władza pracodawcy.

Prawo pracy reaguje w celu stawienia czoła korporacyjnej decentralizacji, oszustwom związanym z pracą i wyzwaniom globalizacji. Niezależnie od specyficznych wypadków poszczególnych państw, prawo to zostało wzmocnione - co najmniej w niektórych regionach - przez standardy i rodzaje ochrony uzupełniające tradycyjne prawo pracy. Są dowody na to, że ta gałąź prawa dysponuje wystarczającymi instrumentami, aby zmierzyć się z dalszymi zmianami dotyczącymi sposobów pracy, które najprawdopodobniej pojawią się w nadchodzących latach.

Sprawą wielkiej wagi jest uniwersalizacja praw związanych z pracą i ich stosowanie we wszystkich państwach $\mathrm{w}$ drodze różnych środków i mechanizmów. Istnieje wspólne jądro tych praw, powtarzające się $\mathrm{w}$ różnych aktach, które musi być respektowane we wszystkich państwach. Widoczne są zmiany w systemie źródeł prawa. Niektóre instrumenty prawne zdają się wskazywać, że międzynarodowa polityka społeczna zmierza do stosowania co najmniej niektórych praw nie tylko do pracy podporządkowanej, lecz do pracy w ogóle. 